\title{
Selective colorectal cancer cell lysates enhance the immune function of mature dendritic cells in vitro
}

\author{
LIHONG CHEN* ${ }^{*}$, DU MENG ${ }^{*}$, LEI ZHAO, RUI LIU, PEISONG BAI, LE WANG and JUXIANG XIAO \\ Department of Oncology, First Affiliated Hospital of the Medical School of Xi'an Jiaotong University, \\ Xi'an, Shaanxi 710061, P.R. China
}

Received December 21, 2013; Accepted September 24, 2014

DOI: $10.3892 / \mathrm{mmr} .2014 .2930$

\begin{abstract}
The aim of the present study was to determine the most effective antigen with which to mature dendritic cells (DCs). The immune function of DCs loaded with lysates from three different colorectal cancer cell lines was compared. DCs were induced using granulocyte macrophage colony-stimulating factor, interleukin (IL)- 4 and tumor necrosis factor- $\alpha$ from the peripheral blood mononuclear cells of patients with colorectal cancer, and loaded with lysates from Colo320, SW480 and SW620 colorectal cancer cell lines, respectively. Autogenous T cells were co-cultured with mature DCs. Surface markers and the secretory function of mature DCs and stimulated T cells were then analyzed. MTT assays were used to evaluate the killing capacity of autogenous cytotoxic T lymphocytes (CTLs). Compared with control, cluster of differentiation (CD)1a, CD83 and CD86, and human leukocyte antigen-DR expression levels were significantly higher in DCs matured using cancer cell lysates. In addition, IL-12 secretion levels were elevated. Autogenous T cells stimulated with DCs that were matured using cancer cell lysates showed a higher proliferation capacity, increased interferon- $\gamma$ secretion levels and stronger cytotoxic abilities compared with control cells. Among the three cell lines, SW480 lysates were most effective at promoting DC and T cell function. The results showed that SW480 lysates are more efficient than Colo320 and SW620 lysates in inducing DC immune function and activating the antitumor function of autogenous $\mathrm{T}$ cells.
\end{abstract}

\footnotetext{
Correspondence to: Professor Juxiang Xiao, Department of Oncology, First Affiliated Hospital of Medical School of Xi'an Jiaotong University, 277 Yanta West Road, Xi'an, Shaanxi 710061, P.R. China

E-mail: juxiangxiaoprof@163.com

*Contributed equally
}

Key words: tumor immunity, tumor vaccine, dendritic cell, colorectal cancer, tumor cell lysates

\section{Introduction}

Dendritic cells (DCs) were first identified by Steinman and Cohn in mouse spleen in 1973 (1), and were so named due to the dendritic protrusions on the surface of the cell membrane. DCs are important in the initiation of and participation in immunoreactions. They are the only antigen-presenting cells (APCs) that activate naïve T cells (2). Immature DCs uptake and process foreign antigens in peripheral tissues. Following maturation, DCs migrate to $\mathrm{T}$ cell regions within lymph nodes, present antigens to $\mathrm{T}$ cells and directly activate the $\mathrm{T}$ cells by combining with them (3). DCs also activate Th1 cells indirectly by secreting interleukin (IL)-12, thereby inducing stronger immunoreactions (4).

It has been shown that DCs cultured in vitro have a similar immunological function to DCs isolated directly from tissues (5). Previous reports have shown that DCs matured using tumor cell lysates are able to induce effective antitumor immunoreactions $(6,7)$. There have also been reports of DC vaccines being applied in leukemia, bladder cancer, parathyroid carcinoma and non-small-cell lung cancer, where affirmatory antitumor immunoreactions have been observed $(8,9)$.

Potent immunogenic antigens are required to effect the immunological functions of DCs. Different antigens give rise to particular DC immunoreactions. The diverse protein and nucleic acid composition and content in different types of tumors results in differences in immunogenicity (10). Following repeated freeze-thaw cycles or ultrasonic grinding, tumor cells may be used as a form of highly immunogenic antigen (11). Following maturation with tumor cell lysates, DCs may be used to generate antitumor vaccines. Rapid and strong in vivo antitumor effects have been observed in mice following infusion with DC vaccines, and antitumor effects have been observed with the first infusion (11). There is growing interest in developing colorectal cancer immunotherapeutics in the form of DC vaccines (12). However, the weak immunogenicity of cells from patients with colorectal cancer and the low specificity of tumor antigen impacts upon the application of DC vaccines in colorectal cancer therapy. Therefore, it is important to identify suitable tumor antigens to present to immunocytes that stimulate effective immunoreactions.

Tumor cell lysates are easily prepared and contain a full set of tumor antigens. These types of tumor antigens are able to induce immunoreactions against multiple unknown 
tumor-associated antigens (TAA) simultaneously. This minimizes the possibility of tumor immune escape and eliminates the need to identify specific tumor antigens $(13,14)$. In order to evaluate the feasibility of using DC vaccines in colorectal cancer therapy and to identify appropriate tumor antigens, the antitumor immunoreactions of DCs loaded with colorectal cancer cell lysates in vitro were investigated. DCs were induced from $\mathrm{CD}_{1} 4^{+}$mononuclear cells in peripheral blood, and loaded with Colo320, SW480 and SW620 colorectal cancer cell lysates. Changes in morphology, surface markers and the secretory capacity of matured DCs, as well as their ability to stimulate autogenous $\mathrm{T}$ cells were examined. This preliminary study aimed to initiate investigation into the therapeutic effects of DC vaccines in response to colorectal cancer in vivo and in clinical practice.

\section{Materials and methods}

Preparation of colorectal cancer cell lysates. Colo320, SW480 and SW620 colorectal cancer cells were obtained from the Department of Immunopathogenesis of Xi'an Jiaotong University (Xi'an, China), and cultured in RPMI-1640 media (Hangzhou Sijiqing Biological Engineering Materials Co., Ltd., Hangzhou, China) containing 10\% fetal calf serum (FCS; Hangzhou Sijiqing Biological Engineering Materials Co., Ltd.). Cells in the logarithmic phase of growth were obtained and suspended in phosphate-buffered saline (PBS; Xi'an Chemical Reagent Factory, Xi'an, China) at a cell density of $1 \times 10^{7}-10^{8}$ cells $/ \mathrm{ml}$. Cells were frozen in liquid nitrogen, thawed rapidly at $37^{\circ} \mathrm{C}$ and refrozen four times in order to produce cell lysates. The supernatants containing the protein lysates were collected following centrifugation $(2,000 \mathrm{x} \mathrm{g}$ for $20 \mathrm{~min}$ ) and filtered using a $0.22-\mu \mathrm{m}$ microporous film (Haining Guodian Taoyuan Medicinal Chemical Instrument Factory, Haining, China). Absorbance at $260 \mathrm{~nm}$ and $280 \mathrm{~nm}$ was examined using a spectrophotometer (DU530; Beckman Coulter, Pasadena, CA, USA) to determine the protein content.

Induction, culture and maturation of DCs. Peripheral blood mononuclear cells (PBMCs) were separated from the peripheral blood of patients with colorectal cancer. Blood samples were obtained in the First Affiliated Hospital of the Medical School of Xi'an Jiaotong University in 2006. Five patients were included (age, 56-74 years, median age 56 years; one female patient, four male patients). All patients had primary tumors, underwent radical surgery and received eight FOLFOX (folinic acid, 5-fluorouracil and oxaliplatin) regimen cycles. No patient underwent radiotherapy. Informed consent was obtained from each volunteer prior to blood samples being drawn. PBMCs were cultured in RPMI-1640 media containing 10\% FCS. Following removal of non-adherent cells, granulocyte macrophage colony-stimulating factor (GM-CSF; $500 \mathrm{ng} / \mathrm{ml}$, Xiamen Amoytop Biotech Co., Ltd., Fujian, China) and IL-4 (12.5 ng/ml, R\&D Systems, Inc., Minneapolis, MN, USA) were added to induce the development of PBMCs into DCs. Colorectal cancer cell lysates and tumor necrosis factor- $\alpha$ (TNF- $\alpha$; Shanghai Saida Biological Pharmaceutical Industry Company Limited, Shanghai, China) were added at day 5, and mature DCs were harvested from day 7 to day 10 . The growth status of cells was observed daily using an inverted microscope (TE2000U; Nikon Corporation, Tokyo, Japan). DC ultra-microstructure was observed using transmission electron microscopy (TEM) (H-7650; Hitachi, Tokyo, Japan). Protrusions on the cell surface were observed using scanning electron microscopy (SEM) (S-3400; Hitachi).

Flow cytometric analyses. DCs were harvested at day 7. Cells were washed twice and resuspended in PBS at a cell density of $1 \times 10^{5}$ cells $/ \mathrm{ml}$. Cell solution $(200 \mu \mathrm{l})$ was added to each tube. Cells were incubated with various mouse-anti-human monoclonal antibodies for $30 \mathrm{~min}$ at $4^{\circ} \mathrm{C}$ in darkness. Following incubation, cells were washed to remove unconjugated antibodies. Cells were collected, fixed in paraformaldehyde and examined using flow cytometry (Epics Elite flow cytometer; Beckman Coulter). The following antibodies were used: Phycoerythrin (PE)-CD83 (monoclonal mouse anti-human, cat. no. 561959; BD Pharmingen, San Diego, CA, USA), PE-CD86 (monoclonal mouse anti-human, cat. no. 560957; BD Pharmingen), PE-HLA-DR (monoclonal mouse anti-human, cat. no. 560943; BD Pharmingen), fluorescein isothiocyanate (FITC)-CDla (monoclonal mouse anti-human, cat. no. 560945; BD Pharmingen), PE-isotype (polyclonal mouse anti-human, cat. no. 554680; BioLegend, Inc., San Diego, CA, USA), and FITC-isotype (polyclonal mouse anti-human, cat. no. 551954; BioLegend, Inc.).

ELISA analyses. To compare secretory levels of DCs prior to maturation with those following maturation, IL-12, IL-10 and interferon- $\gamma($ IFN- $\gamma$ ) levels in the media supernatant were examined using ELISA kits (Shanghai Senxiong Technology Industrial Co., Ltd., Shanghai, China). Absorbance was determined at $492 \mathrm{~nm}$.

${ }^{3} H$-TdR incorporation. The multiplication capacity of autogenous T cells was detected by ${ }^{3} \mathrm{H}-\mathrm{TdR}$ (Third Chemical Reagent Factory of Beijing, Beijing, China) incorporation. DCs and autogenous T cells were co-cultured in 96 -well plates. ${ }^{3} \mathrm{H}$-TdR was added to each well (10 $\mu \mathrm{Ci}$ per well). The actual radioactive specific activity was $3.7 \times 10^{6} \mathrm{~Bq}$ for each well. Following co-culture for $72 \mathrm{~h}$, cells were collected on glass fiber filter paper, washed twice and air dried. The filter paper was placed into scintillation vials, and counts per minute (cpm) values were determined using a $\beta$ liquid scintillation counter. The stimulation index (SI) was calculated as:

$$
\begin{gathered}
\text { SI }(\%)=(\mathrm{cpm} \text { of samples }-\mathrm{cpm} \text { of blank control }) /(\mathrm{cpm} \text { of } \\
\text { negative control }-\mathrm{cpm} \text { of blank control }) \times 100 .
\end{gathered}
$$

The SIs of T cells that had been stimulated using three types of cancer cell lysate-loaded DCs was calculated. The non-stimulated $\mathrm{T}$ cell group was used as a negative control, whilst $\mathrm{T}$ cells stimulated with DCs matured using TNF- $\alpha$ were considered a blank control.

MTT assays. The killing capacity of autogenous cytotoxic T lymphocytes (CTLs) was detected using an MTT assay (Sigma, St. Louis, MO, USA). CTLs were induced from T cells following co-culture with DCs for $72 \mathrm{~h}$. CTLs (effectors) and tumor cells (targets) were co-cultured at a ratio of 10:1 for $16 \mathrm{~h}$ in 96-well plates. MTT was then added to each well $(5 \mathrm{mg} / \mathrm{ml})$. 

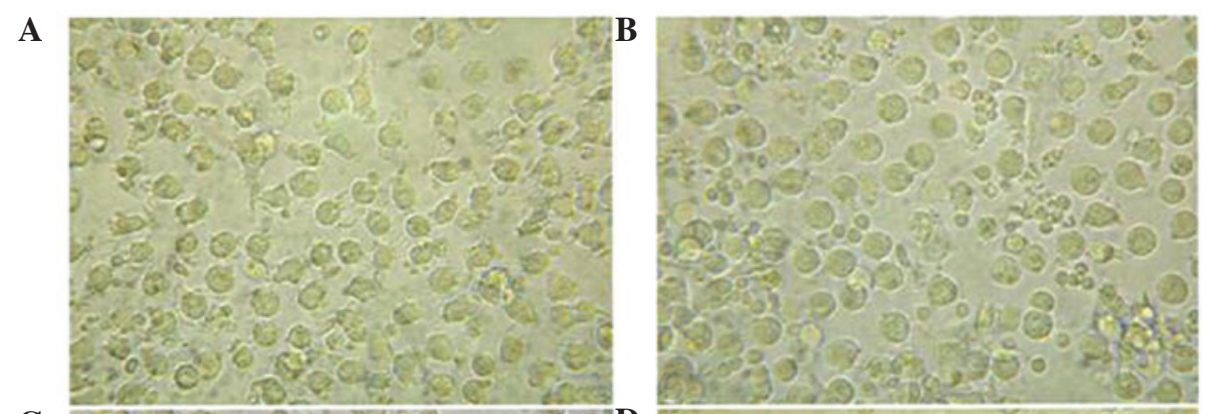

C
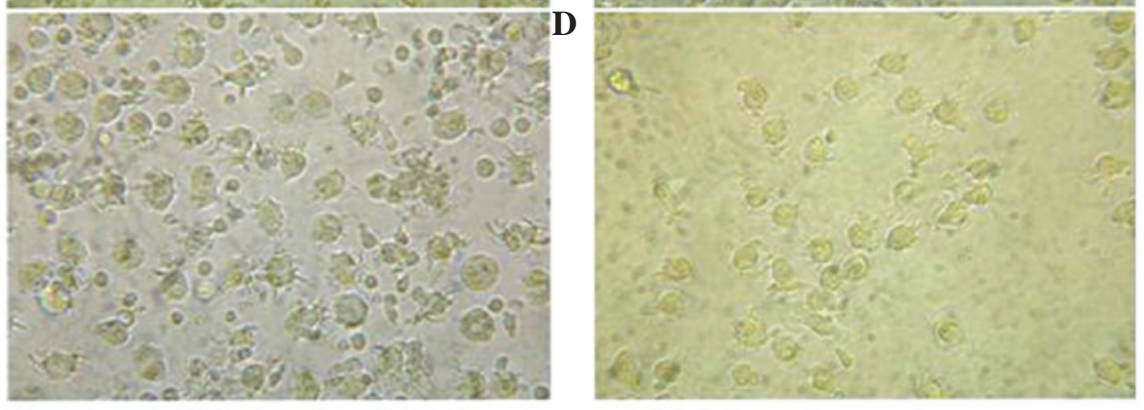

Figure 1. DC morphology at day 7. (A) $\mathrm{DC}_{\mathrm{TNF}}$ presented as single suspended cells with typical dendritic protrusions (magnification, $\left.\mathrm{x} 250\right)$. (B) $\mathrm{DC}_{32},(\mathrm{C}) \mathrm{DC}_{480}$ and (D) $\mathrm{DC}_{620}$ cells showed more evident and numerous protrusions and features compared with $\mathrm{DC}_{\mathrm{TNF}}$ cells. DC, dendritic cells; $\mathrm{DC}_{\mathrm{TNF}}, \mathrm{DC}$ cells loaded with TNF- $\alpha$ only. TNF, tumor necrosis factor.

At $4 \mathrm{~h}$, dimethyl sulfoxide was added to terminate the reactions. The optical density (OD) at $570 \mathrm{~nm}$ was measured using a spectrophotometer (DU530; Beckman Coulter) to calculate the killing activity. Killing activity (\%) was calculated using: [1-(OD value of samples-OD value of effectors) / OD value of targets] $\mathrm{x} 100$. The killing rates of CTLs stimulated by the three types of cancer cell lysate-loaded DCs were calculated. The non-stimulated T cell group was used as a negative control, whilst CTLs stimulated with DCs matured using TNF- $\alpha$ were considered a blank control.

Statistical analyses. SPSS software version 17.0 was used for all statistical analyses (SPSS, Inc., Chicago, IL, USA). One-way analysis of variance and post hoc tests were used to process multi-group data. Paired-sample t-tests were used to compare the same samples prior to and following treatment. $\mathrm{P}<0.05$ was considered to indicate a statistically significant difference.

\section{Results}

DC morphology. PBMCs were separated from peripheral blood and grew adherently as uniform-sized round cells. Following 7 days in culture with GM-CSF and IL-4, PBMCs were induced to become DCs. DCs in suspension were observed to be single large round cells with dendritic protrusions on the cell surface. DCs that were loaded using Colo320 $\left(\mathrm{DC}_{320}\right)$, SW480 $\left(\mathrm{DC}_{480}\right)$ and SW620 $\left(\mathrm{DC}_{620}\right)$ lysates had more protrusions on the cell surface than DCs loaded using TNF- $\alpha$ ( $\left.\mathrm{DC}_{\mathrm{TNF}}\right)$ alone. In addition, the protrusions appeared more evident and numerous in the cell lysate-loaded DCs (Fig. 1). There were no morphological differences observed among $\mathrm{DC}_{320}, \mathrm{DC}_{480}$ and $\mathrm{DC}_{620}$. Using SEM, protrusions could be observed more clearly, and the DCs were found to be irregularly shaped with rough cell surfaces (Fig. 2A). Cell protrusions and pseudopodia were
A

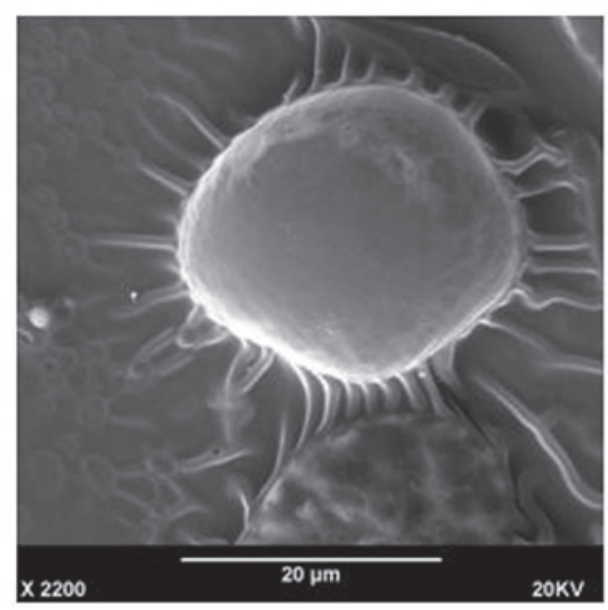

B

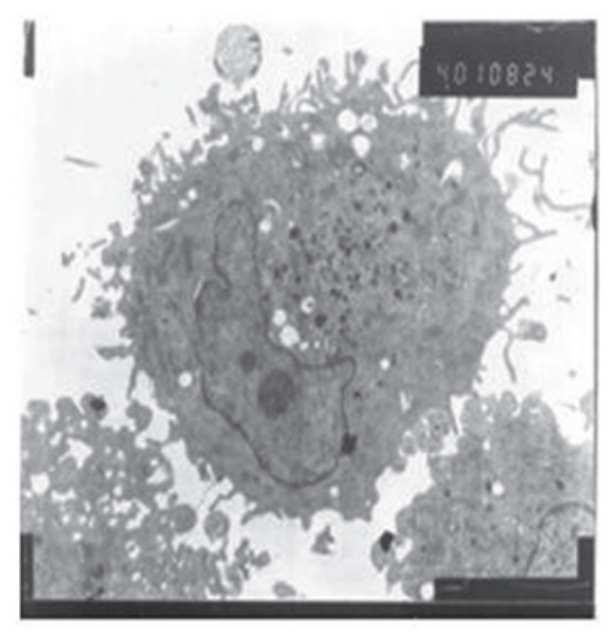

Figure 2. DC morphology using electron microscopy (magnificaiton, x2,220). (A) Protrusions were clearly observed using scanning electron microscopy. DCs were irregularly shaped with rough cell surfaces. (B) Cell protrusions and pseudopodium were observed using transmission electron microscopy. DCs, dendritic cells. 
Table I. Surface markers of different DCs.

\begin{tabular}{lllll}
\hline & $\mathrm{DC}_{\mathrm{TNF}}(2)$ & $\mathrm{DC}_{320}(3)$ & $\mathrm{DC}_{480}(4)$ & $\mathrm{DC}_{620}(5)$ \\
\hline CD1a & $23.95 \pm 8.16$ & $37.94 \pm 9.59$ & $47.94 \pm 11.20$ & $38.08 \pm 9.31$ \\
CD83 & $26.06 \pm 4.34$ & $35.01 \pm 5.60$ & $49.02 \pm 6.64$ & $42.15 \pm 8.47$ \\
CD86 & $53.50 \pm 4.45$ & $85.64 \pm 5.56$ & $90.29 \pm 3.46$ & $84.24 \pm 4.60$ \\
HLA-DR & $57.79 \pm 7.97$ & $85.64 \pm 3.66$ & $87.60 \pm 3.51$ & $86.78 \pm 4.83$ \\
\hline
\end{tabular}

Data are presented as the mean \pm standard deviation of five samples. DC, dendritic cell; CD, cluster of differentiation; HLA, human leukocyte antigen.

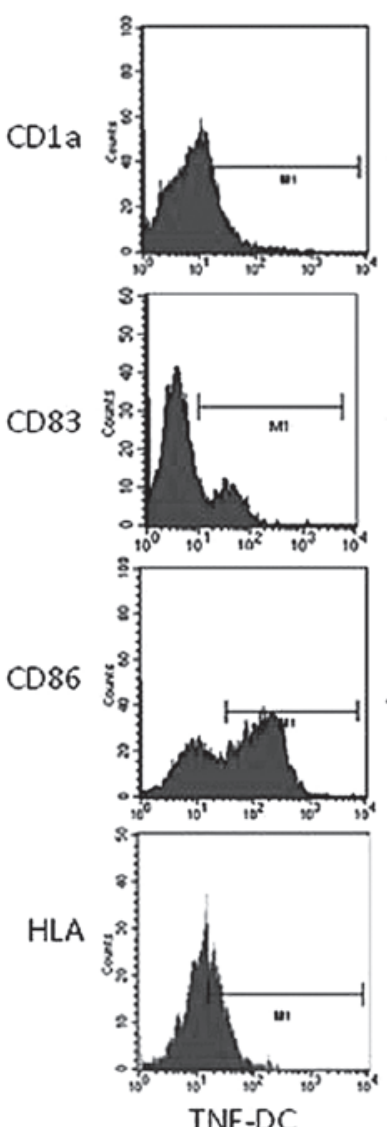

TNF-DC
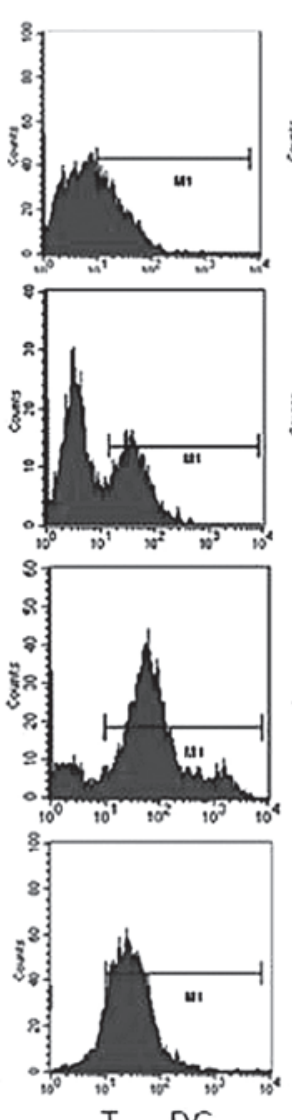

$\mathrm{T}_{320}-\mathrm{DC}$
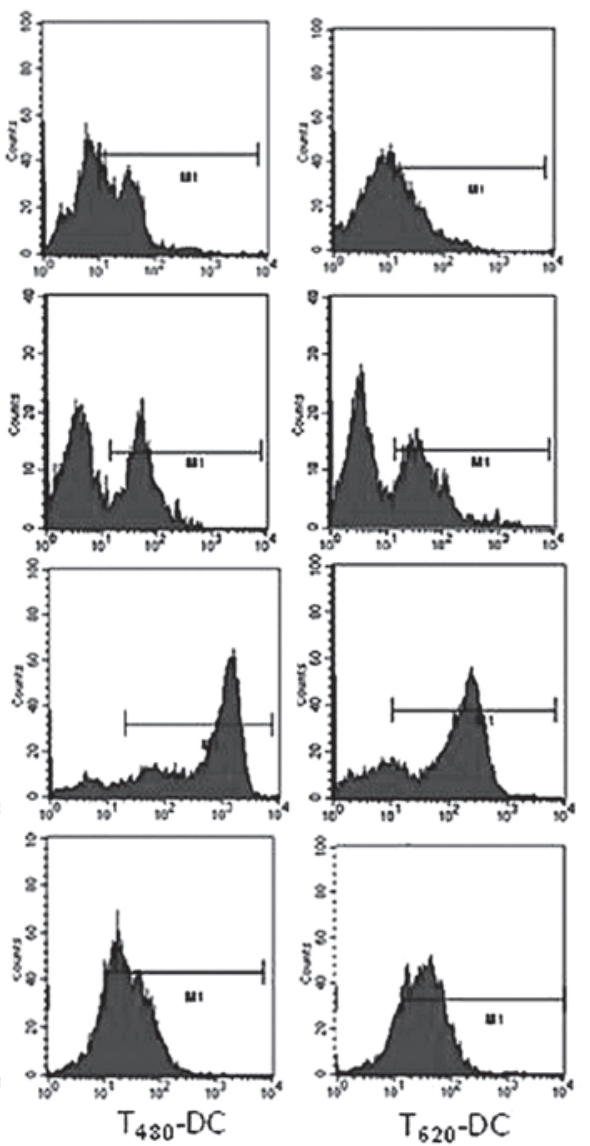

Figure 3. Surface marker expression based on flow cytometry analyses. DC, dendritic cell; CD, cluster of differentiation; HLA, human leukocyte antigen; TNF, tumor necrosis factor.

observed using TEM. The electronic density of the cells was uneven, and there was abundant cytoplasm, rough endoplasmic reticulum hyperplasia and clustered glycogen. The nucleus was large, irregular and contained abundant karyoplasm (Fig. 2B).

Expression of CDIa, CD83, CD86 and HLA-DR is elevated in mature DCs. CD1a, CD83, CD86 and HLA-DR were detected in mature DCs. Compared with $\mathrm{DC}_{\mathrm{TNF}}, \mathrm{CD} 1 \mathrm{a}, \mathrm{CD} 83$ and CD86 expression was significantly higher in $\mathrm{DC}_{320}, \mathrm{DC}_{480}$, and $\mathrm{DC}_{620}(\mathrm{P}<0.05)$. Furthermore, the expression of the three surface markers was significantly higher in $\mathrm{DC}_{480}$ than in $\mathrm{DC}_{320}$ and $\mathrm{DC}_{620}(\mathrm{P}<0.05)$. CD83 expression in $\mathrm{DC}_{620}$ was higher than that in $\mathrm{DC}_{320}(\mathrm{P}<0.05)$. The expression levels of the surface markers are shown in Figs. 3 and 4, as well as Table I. Statistical analyses are shown in Table II.

Elevated secretory activity of mature DCs. Compared with immature DCs, the IL-12 levels from $\mathrm{DC}_{320}, \mathrm{DC}_{480}, \mathrm{DC}_{620}$ and $\mathrm{DC}_{\mathrm{TNF}}$ cells were significantly elevated $(\mathrm{P}<0.05)$. There was a significantly higher secretion of IL-12 from $\mathrm{DC}_{320}, \mathrm{DC}_{480}$ and $\mathrm{DC}_{620}$ cells compared with $\mathrm{DC}_{\mathrm{TNF}}$ cells $(\mathrm{P}<0.05)$. IL-12 secretion from $\mathrm{DC}_{480}$ cells was the highest among the three cancer cell lysate-loaded DCs. No differences were observed in IL-12 levels between $\mathrm{DC}_{320}$ and $\mathrm{DC}_{620}$ cells (Table III). IL-10 and IFN- $\gamma$ were not detected in immature $\mathrm{DCs}, \mathrm{DC}_{\mathrm{TNF}}$ or cancer cell lysate-loaded DCs. 
Table II. Statistical analyses of surface marker expression.

P-value

(2) vs. (3)

(2) vs. (4)

(2) vs. (5)

(3) vs. (4)

(3) vs. (5)

(4) vs. (5)

\begin{tabular}{|c|c|c|c|c|c|c|}
\hline CD1a & $<0.001$ & $<0.001$ & $<0.001$ & 0.03 & 0.95 & 0.04 \\
\hline CD83 & $<0.001$ & $<0.001$ & $<0.001$ & 0.02 & 0.03 & 0.03 \\
\hline CD86 & $<0.001$ & $<0.001$ & $<0.001$ & 0.04 & 0.86 & 0.03 \\
\hline HLA-DR & $<0.001$ & $<0.001$ & $<0.001$ & 0.44 & 0.65 & 0.75 \\
\hline
\end{tabular}

(2), (3), (4) and (5) indicate $\mathrm{DC}_{\mathrm{TNF}}, \mathrm{DC}_{320}, \mathrm{DC}_{480}$ and $\mathrm{DC}_{620}$, respectively. TNF, tumor necrosis factor; DC, dendritic cell; $\mathrm{CD}$, cluster of differentiation; HLA, human leukocyte antigen.

Table III. IL-12 secretion levels of DCs loaded using different antigens.

\begin{tabular}{|c|c|c|c|c|c|}
\hline & $\operatorname{ImDC}(1)$ & $\mathrm{DC}_{\mathrm{TNF}}(2)$ & $\mathrm{DC}_{320}(3)$ & $\mathrm{DC}_{480}(4)$ & $\mathrm{DC}_{620}(5)$ \\
\hline IL-12 (pg/ml) & $8.738 \pm 0.53^{\mathrm{abcd}}$ & $85.20 \pm 4.10^{\mathrm{bcd}}$ & $119.92 \pm 4.94^{\mathrm{aef}}$ & $139.44 \pm 8.95^{\mathrm{ag}}$ & $122.25 \pm 6.46$ \\
\hline
\end{tabular}

Table IV. IFN- $\gamma$ secretion levels of T cells stimulated using different DCs.

\begin{tabular}{|c|c|c|c|c|c|}
\hline & $\begin{array}{c}\text { Non-stimulated } \\
\text { T cells }(1)\end{array}$ & $\mathrm{DC}_{\mathrm{TNF}}-\mathrm{T}(2)$ & $\mathrm{DC}_{320}-\mathrm{T}(3)$ & $\mathrm{DC}_{480}-\mathrm{T}(4)$ & $\mathrm{DC}_{620}-\mathrm{T}(5)$ \\
\hline $\mathrm{IFN}-\gamma(\mathrm{pg} / \mathrm{ml})$ & $8.649 \pm 1.53^{\mathrm{abcd}}$ & $182.28 \pm 7.13^{\mathrm{bcd}}$ & $214.88 \pm 4.94^{\mathrm{ef}}$ & $237.39 \pm 7.69^{\mathrm{g}}$ & $215.76 \pm 5.59$ \\
\hline
\end{tabular}

Table V. SI of T cells stimulated using different DCs.

\begin{tabular}{|c|c|c|c|c|c|}
\hline & $\begin{array}{l}\text { Non-stimulated } \\
\text { T cells (1) }\end{array}$ & $\mathrm{DC}_{\mathrm{TNF}}-\mathrm{T}(2)$ & $\mathrm{DC}_{320}-\mathrm{T}(3)$ & $\mathrm{DC}_{480}-\mathrm{T}(4)$ & $\mathrm{DC}_{620^{-}} \mathrm{T}(5)$ \\
\hline SI & $2.13 \pm 0.76^{\mathrm{abcd}}$ & $5.89 \pm 2.79^{\mathrm{bcd}}$ & $10.56 \pm 3.11^{\mathrm{ef}}$ & $14.56 \pm 4.52^{\mathrm{g}}$ & $11.58 \pm 2.16$ \\
\hline
\end{tabular}

${ }^{\text {ap }}<0.05$ vs. (2), ${ }^{b} \mathrm{P}<0.05$ vs. (3), ${ }^{\mathrm{c}} \mathrm{P}<0.05$ vs. (4), ${ }^{\mathrm{d}} \mathrm{P}<0.05$ vs. $(5),{ }^{\mathrm{e}} \mathrm{P}=0.02$ vs. (4), ${ }^{\mathrm{f}} \mathrm{P}=0.99$ vs. $5,{ }^{\mathrm{g}} \mathrm{P}=0.02$ vs. 5 . Data are presented as the mean \pm standard deviation of five samples. SI, stimulation index; DC, dendritic cell; TNF, tumor necrosis factor.

Stimulation of the secretory activity of autogenous $T$ cells is elevated in mature DCs. The IFN- $\gamma$ and IL-10 levels in the supernatant of $\mathrm{T}$ cell media were evaluated to determine the secretory activity of the $\mathrm{T}$ cells. Compared with the non-stimulated $\mathrm{T}$ cells (T-control), IFN- $\gamma$ levels were significantly higher in $\mathrm{T}$ cells stimulated using $\mathrm{DC}_{320}$ $\left(\mathrm{DC}_{320}-\mathrm{T}\right), \mathrm{DC}_{480}\left(\mathrm{DC}_{480}-\mathrm{T}\right), \mathrm{DC}_{620}\left(\mathrm{DC}_{620}-\mathrm{T}\right)$ and $\mathrm{DC}_{\mathrm{TNF}}$ $\left(\mathrm{DC}_{\mathrm{TNF}}-\mathrm{T} ; \mathrm{P}<0.05\right)$. The order of IFN- $\gamma$ secretion was:
$\mathrm{DC}_{480}-\mathrm{T}>\mathrm{DC}_{620}-\mathrm{T} \approx \mathrm{DC} 320-\mathrm{T}>\mathrm{DC}_{\mathrm{TNF}}-\mathrm{T}$ (Table IV). IL-10 was not detected in any $\mathrm{T}$ cells.

Elevated multiplication capacity of $T$ cells stimulated using mature DCs. Compared with non-stimulated T cells, the multiplication capacity of T cells stimulated using mature DCs was significantly elevated. The order of $\mathrm{T}$ cell multiplication capacity was: $\mathrm{DC}_{480}-\mathrm{T}>\mathrm{DC}_{620}-\mathrm{T} \approx \mathrm{DC}_{320}-\mathrm{T}>\mathrm{DC}_{\mathrm{TNF}}-\mathrm{T}$ (Table V). 
Table VI. Killing rates of different DCs in response to different colorectal cancel cell lines.

\begin{tabular}{lccccc}
\hline Killing rate (\%) & $\mathrm{DC}_{320^{-}-\mathrm{CTL}(1)}$ & $\mathrm{DC}_{480}-\mathrm{CTL}(2)$ & $\mathrm{DC}_{620^{-}}-\mathrm{CTL}(3)$ & $\mathrm{DC}_{\mathrm{TNF}}-\mathrm{CTL}(4)$ & $\begin{array}{c}\text { Non-stimulated } \\
\mathrm{T} \text { cells }(5)\end{array}$ \\
\hline $\begin{array}{l}\text { In response } \\
\text { to Colo320 cells }\end{array}$ & $53.29 \pm 3.08^{\text {abcd }}$ & $56.20 \pm 2.97^{\mathrm{cde}}$ & $49.05 \pm 4.05^{\mathrm{cd}}$ & $27.09 \pm 2.98^{\mathrm{d}}$ & $10.23 \pm 0.83$ \\
$\begin{array}{l}\text { In response } \\
\text { to SW480 cells }\end{array}$ & $53.29 \pm 3.08^{\mathrm{cdfg}}$ & $56.20 \pm 2.97^{\mathrm{cdh}}$ & $49.05 \pm 4.05^{\mathrm{cd}}$ & $27.09 \pm 2.98^{\mathrm{d}}$ & $10.23 \pm 0.83$ \\
$\begin{array}{l}\text { In response } \\
\text { to SW620 cells }\end{array}$ & $47.62 \pm 4.71^{\text {acdi }}$ & $58.66 \pm 4.65^{\mathrm{cdj}}$ & $53.42 \pm 4.45^{\mathrm{cd}}$ & $25.25 \pm 3.12^{\mathrm{d}}$ & $11.63 \pm 0.83^{\mathrm{a}}$ \\
& & & & &
\end{tabular}

${ }^{\mathrm{a}} \mathrm{P}=0.63$ vs. (2), ${ }^{\mathrm{b}} \mathrm{P}=0.01$ vs. (3), ${ }^{\mathrm{c}} \mathrm{P}<0.001$ vs. (4), ${ }^{\mathrm{d}} \mathrm{P}<0.001$ vs. (5), ${ }^{\mathrm{e}} \mathrm{P}=0.02$ vs $(3),{ }^{\mathrm{f}} \mathrm{P}<0.001$ vs. (2), ${ }^{\mathrm{g}} \mathrm{P}=0.079$ vs. (3), ${ }^{\mathrm{h}} \mathrm{P}<0.001$ vs. $(3)$, ${ }^{\mathrm{i}} \mathrm{P}=0.03$ vs. (3), ${ }^{\mathrm{j}} \mathrm{P}=0.047$ vs. (3). Data are presented as the mean \pm standard deviation of five samples. DC, dendritic cell, TNF, tumor necrosis factor; CTL, cytotoxic T lymphocyte.

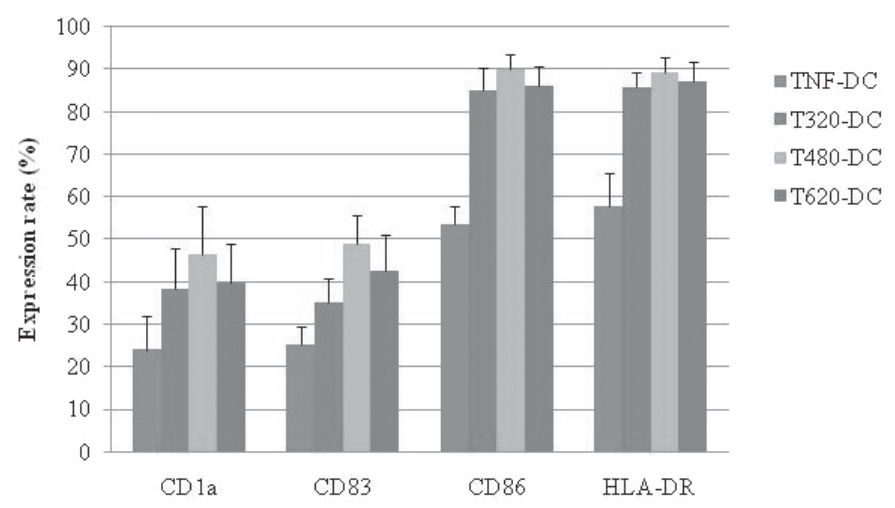

Figure 4. DC surface markers. DC, dendritic cell, TNF, tumor necrosis factor- $\alpha$. ; CD, cluster of differentiation; HLA, human leukocyte antigen.

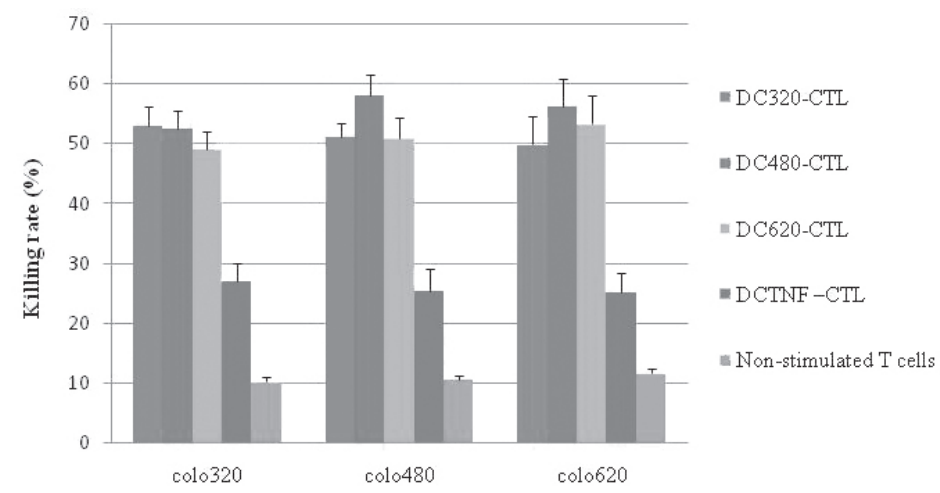

Figure 5. Killing rates of specific DCs in response to various colorectal cancer cells. DC, dendritic cell; CTL, cytotoxic T lymphocyte; TNF, tumor necrosis factor- $\alpha$.

Comparison of CTL killing activities in response to different cancer cell lines. Compared with non-stimulated T cells, CTLs stimulated using mature DCs exhibited a stronger killing activity $(\mathrm{P}<0.05)$. DCs loaded with tumor cell lysates resulted in more intense CTL killing activity than that in $\mathrm{DC}_{\mathrm{TNF}}(\mathrm{P}<0.05)$. $\mathrm{DC}_{320}-\mathrm{CTL}$ and $\mathrm{DC}_{480}-\mathrm{CTL}$ exhibited similar killing activities in response to Colo320 cells ( $\mathrm{P}>0.05)$, and both were stronger than $\mathrm{DC}_{620}-\mathrm{CTL}(\mathrm{P}<0.05) . \mathrm{DC}_{480}-\mathrm{CTL}$ displayed increased killing rates compared with $\mathrm{DC}_{320}-\mathrm{CTL}$ and $\mathrm{DC}_{620}-\mathrm{CTL}$ in SW480 cells $(\mathrm{P}<0.05)$. The order of killing rates in response to SW620 cells were as follows: $\mathrm{DC}_{480}-\mathrm{CTL}>\mathrm{DC}_{620^{-}}$ CTL $>\mathrm{DC}_{320}-\mathrm{CTL}(\mathrm{P}<0.05)$. This suggests that DCs loaded using SW480 may trigger greater or equal killing activities of CTLs to the three types of cancer cells compared with DCs loaded with TNF- $\alpha$ alone (Table VI, Fig. 5).

\section{Discussion}

The majority of DCs present in tissues are immature. Immature DCs become mature when stimulated by antigens or matura- 
tion signals. Following maturation, DCs lose their endocytic capabilities and begin to secrete IL-1 and IL-18, express chemotactic factor receptors, elevate cell surface expression and stability of MHC-I and II molecules, and upregulate the expression of costimulatory molecules (15). The predominant features of mature DCs are: Dendritic or burr-shaped protrusions on the cell surface; strong expression of MHC-I molecules, MHC-II molecules, B7-1/CD80 and B7-2/CD86 on the cell surface $(16,17)$; intense antigen-processing capabilities; the ability to activate T cells (18); and the synthesis and secretion of IL-12 (19). In the current study, subsequent to loading with tumor cell lysates (antigens), DCs gradually began to develop mature morphologies and appeared as scattered suspended large cells with dendritic protrusions on the membrane surface. CD1a, CD83, CD86 and HLA-DR molecules were detected on the surfaces of DCs, and IL-12 secretion was elevated. These results indicate that Colo320, SW480 and SW620 cell lysates induce $\mathrm{DC}$ maturation. Compared with $\mathrm{DC}_{\mathrm{TNF}}$, cancer cell lysate-loaded DCs exhibited more mature morphologies, with increased secretory activity and higher expression levels of MHCs and costimulatory molecules. This suggests that cancer cell lysates may increase the yield of mature DCs with antigen-processing abilities compared with TNF- $\alpha$. Among the three types of cancer cell lysate-loaded DCs, $\mathrm{DC}_{480}$ showed the more features indicative of maturation, demonstrating that SW480 cell lysates may induce the development of powerful mature DCs that activate further immunoreactions.

IL-12, which is secreted by DCs, is an important Th1-type cytokine that promotes the integration of the innate and adaptive immune responses. IL-12 activates the transcription and expression of Th1-related genes $(20,21)$ and induces Th0 cells to differentiate into Th1 cells, thereby leading to Th1-type immunoreactions, including IFN- $\gamma$ secretion and CTL activation (22). IL-12 is only secreted in small quantities by immature DCs. However, IL-12 secretion is elevated following DC maturation. Elevated IL-12 secretion is determined by a balance of IL-12 inducers and inhibitors (23). IFN- $\gamma$ is an IL-12 inducer, whereas IL-10 inhibits IL-12 secretion (24). In the current study, IL-12 secretion from mature DCs was markedly higher than that from immature DCs. Furthermore, DCs loaded using cancer cell lysates, in particular, $\mathrm{DC}_{480}$, secreted greater quantities of IL-12 compared with $\mathrm{DC}_{\mathrm{TNF}}$. This indicates that cancer cell lysates, particularly SW480 cell lysates, may induce maturation of DCs and Th1-type immunoreactions.

DCs in the circulation are divided into myeloid-lineage DCs (DC1) and lymphoid-lineage DCs (DC2) according to differences in precursor cells, surface markers and cytokine secretion (25). DC1 cells are primarily localized in T cell-rich regions and their function is related to that of T cells. DC2 cells are localized to lymphoid follicle germinal centers within lymph nodes, spleen and mucosa, and their function is related to that of B cells. The primary function of $\mathrm{DC} 1$ is immune activation via activation of CTLs and initiation of Th1-type immunoreactions. By contrast, the primary function of DC2 is immune suppression via secretion of IL-10 and initiation of Th2-type immunoreactions (26-28). In the present study, IL-10 and IFN- $\gamma$ were not detected in the supernatant from mature DCs, whereas increased secretion of IL-12 was detected. This suggests that the mature DCs loaded using cancer cell lysates are DC1 rather than DC2 type cells, and therefore may induce the Th1-type differentiation of Th0 cells and activate antitumor immunoreactions.

DCs are the most powerful APCs and are able to activate $\mathrm{CD}^{+}$and $\mathrm{CD}^{+} \mathrm{T}$ cells (29). An important feature of $\mathrm{DCs}$ is that they activate naïve $\mathrm{T}$ cells and induce a primary immune response. Other APCs, including macrophages and $\mathrm{B}$ cells, induce activated $\mathrm{T}$ cells or memory $\mathrm{T}$ cells but are unable to induce primary immune responses (30). The current study found that the multiplication capacity of autogenous $\mathrm{T}$ cells was significantly elevated following stimulation with mature DCs. Compared with $\mathrm{DC}_{\mathrm{TNF}}$-induced $\mathrm{T}$ cells, $\mathrm{T}$ cells stimulated using cancer cell lysate-loaded DCs had greater multiplication capabilities. This suggests that DCs loaded using cancer cell lysates lead to more intense reactions of $\mathrm{T}$ cells compared with $\mathrm{DC}_{\mathrm{TNF}}$. $\mathrm{DC}_{480}$-induced $\mathrm{T}$ cells exhibited the most rapid multiplication compared with $\mathrm{DC}_{320}-\mathrm{T}$ and $\mathrm{DC}_{620}-\mathrm{T}$, suggesting a more powerful antitumor potential of $\mathrm{DC}_{480}$-induced $\mathrm{T}$ cells.

Following activation by DCs, T cells may in turn impact upon DC function. Through the combination of CD40L on $\mathrm{T}$ cells and CD40 on DCs, activated T cells stimulate DCs to secret greater quantities of IL-12, thus enhancing the stimulation of DCs in response to T cells, which results in increased IFN- $\gamma$ production by $\mathrm{T}$ cells and further Th1-type immunoreactions. This feedback process is termed antigen-presenting cell activated T-T cell assistance (31). T cell immunoreactions induced by tumor antigen-loaded DCs are important in the antitumor immune response. Effective differentiation of Th1 cells is a key step in T cell immunoreactions. Under normal circumstances, Th1 and Th2 cells are in equilibrium. Th1/Th2 drift occurs when this balance is disrupted. Typically, Th1 cells in cancer patients are inhibited, creating Th1 drift, which is a crucial concept in the development of antitumor immunotherapy $(32,33)$. IL-10 is a characteristic cytokine of Th2 cells, whereas IFN- $\gamma$ is specifically secreted by Th1 cells. It is accepted that IFN- $\gamma$ secretion is a marker of the cytotoxic activity of CTLs. Therefore, detection of increased quantities of IFN- $\gamma$ suggests the presence of CTLs (34). Since no IFN- $\gamma$ was previously detected in mature DCs cultured alone, it is evident that IFN- $\gamma$ was secreted by activated $\mathrm{T}$ cells in the co-culture system. High levels of IFN- $\gamma$ but not of IL-10, were detected in activated T cells. Thus, it can be concluded that mature DCs loaded using tumor cell lysates induce Th0 cell to Th1 cell differentiation, and initiate a Th1-type immune response and subsequent cytotoxic effects. The highest levels of IFN- $\gamma$ were detected in $\mathrm{DC}_{480}$-induced $\mathrm{T}$ cells, indicating that $\mathrm{DC}_{480}$ induces the most intense immunoreactions.

CTL activation is a crucial step in antitumor immune reactions $(35,36)$. Activated CTLs kill tumor cells by direct cytotoxicity or by induction of cell apoptosis. The present results demonstrate that mature DCs loaded using cancer cell lysates induce CTL activation, and that activated CTLs had cytotoxic effects against cancer cells. DCs loaded using SW480 cell lysates triggered cytotoxic CTL activity in response to the three types of cancer cells that was greater than or equal to that induced by DCs loaded with TNF- $\alpha$ alone.

The current study shows that mature DCs loaded using cancer cell lysates induce effective antitumor immunoreactions in vitro. Different cancer cell lysates exhibited different 
immunogenicities. SW480 cell lysates appear to have the strongest immunogenicity and to induce the most effective immunoreactions. Currently, the majority of studies on DC vaccines are at the in vitro stage. The lack of unified treatment standards and randomized clinical studies impact upon the in vivo applications of DC vaccines. These problems should be addressed in future studies.

\section{References}

1. Steinman RM and Cohn ZA: Identification of a novel cell type in peripheral lymphoid organs of mice. I. J Exp Med 137: 1142-1162, 1973.

2. Klechevsky E and Banchereau J: Human dendritic cells subsets as targets and vectors for therapy. Ann N Y Acad Sci 1284 24-30,2013.

3. Yanofsky VR, Mitsui H,Felsen D and Carucci JA: Understanding dendritic cells and their role in cutaneous carcinoma and cancer immunotherapy. Clin Dev Immunol 2013: 624123, 2013.

4. Hilkens CM and Isaacs JD: Tolerogenic dendritic cell therapy for rheumatoid arthritis: where are we now? Clin Exp Immunol 172: 148-157, 2013.

5. Ratta M, Curti A, Fogli M, et al: Efficient presentation of tumor idiotype to autologous T cells by CD83(+) dendritic cells derived from highly purified circulating CD14(+) monocytes in multiple myeloma patients. Exp Hematol 28: 931-940, 2000.

6. Hernández-Luna MA, Luria-Pérez R and Huerta-Yépez S Therapeutic intervention alternatives in cancer, using attenuated live bacterial vectors: Salmonella enterica as a carrier of heterologous molecules. Rev Invest Clin 65: 65-73, 2013 (In Spanish).

7. Van De Velde AL, Anguille S and Berneman ZN: Immunotherapy in leukaemia. Acta Clin Belg 67: 399-402, 2012.

8. Yannelli JR, Sturgill J, Foody T and Hirschowitz E: The large scale generation of dendritic cells for the immunization of patients with non-small cell lung cancer (NSCLC). Lung Cancer 47: 337-350, 2005

9. Jarnjak-Jankovic S, Pettersen RD, Saebøe-Larssen S, et al: Evaluation of dendritic cells loaded with apoptotic cancer cells or expressing tumour mRNA as potential cancer vaccines agains leukemia. BMC Cancer 5: 20, 2005.

10. Sabado RL, Miller E, Spadaccia M, et al: Preparation of tumor antigen-loaded mature dendritic cells for immunotherapy. J Vis Exp 78: 2013.

11. Tamir A, Basagila E, Kagahzian A, et al: Induction of tumor-specific T-cell responses by vaccination with tumor lysate-loaded dendritic cells in colorectal cancer patients with carcinoembryonic-antigen positive tumors. Cancer Immunol Immunother 56: 2003-2016, 2007.

12. Dilioglou S, Cruse JM and Lewis RE: Costimulatory function of umbilical cord blood $\mathrm{CD} 14^{+}$and $\mathrm{CD} 34^{+}$derived dendritic cells. Exp Mol Pathol 75: 18-33, 2003

13. Kamigaki T, Kaneko T, Naitoh K, et al: Immunotherapy of autologous tumor lysate-loaded dendritic cell vaccines by a closed-flow electroporation system for solid tumors Anticancer Res 33: 2971-2976, 2013.

14. Aruga A: Dendritic cell-based cancer immunotherapy. Nihon Rinsho 68: 1107-1110, 2010 (In Japanese).

15. Palucka K and Banchereau J: Dendritic-cell-based therapeutic cancer vaccines. Immunity 39: 38-48, 2013.

16. Nagorsen D, Marincola FM and Panelli MC: Cytokine and chemokine expression profiles of maturing dendritic cells using multiprotein platform arrays. Cytokine 25: 31-35, 2004.
17. Yoshida S, Yamamoto K and Tanaka R: Generation of dendritic cells from the ventricular fluid in patients with meningeal carcinomatosis. J Neuroimmunol 140: 172-176, 2003.

18. Merad M, Sathe P, Helft J, et al: The dendritic cell lineage: ontogeny and function of dendritic cells and their subsets in the steady state and the inflamed setting. Annu Rev Immunol 31: 563-604, 2013.

19. Barreira da Silva R and Münz C: Natural killer cell activation by dendritic cells: balancing inhibitory and activating signals. Cell Mol Life Sci 68: 3505-3518, 2011

20. Schreibelt G, Bol KF, Aarntzen EH, et al: Importance of helper T-cell activation in dendritic cell-based anticancer immunotherapy. Oncoimmunology 2: e24440, 2013.

21. Trinchieri G: Interleukin-12 and the regulation of innate resistance and adaptive immunity. Nat Rev Immunol 3: 133-146, 2003.

22. Matias BF, de Oliveira TM, Rodrigues CM, et al: Influence of immunotherapy with autologous dendritic cells on innate and adaptive immune response in cancer. Clin Med Insights Oncol 7: 165-172, 2013.

23. Liao W, Lin JX and Leonard WJ: Interleukin-2 at the crossroads of effector responses, tolerance, and immunotherapy. Immunity 38 : 13-25, 2013.

24. Antony PA and Restifo NP: $\mathrm{CD}^{+} \mathrm{CD} 25^{+} \mathrm{T}$ regulatory cells, immunotherapy of cancer, and interleukin-2. J Immunother 28: 120-128, 2005.

25. Matsuzaki J, Tsuji T, Imazeki I, et al: Immunosteroid as a regulator for Th1/Th2 balance: its possible role in autoimmune diseases. Autoimmunity 38: 369-375, 2005.

26. Hansen M, Met Ö, Svane IM and Anderson MH: Cellular based cancer vaccines: type 1 polarization of dendritic cells. Curr Med Chem 19: 4239-4246, 2012.

27. Wilke CM, Kryczek I and Zou W: Antigen-presenting cell (APC) subsets in ovarian cancer. Int Rev Immunol 30: 120-126, 2011.

28. Satpathy AT, Wu X, Albring JC and Murphy KM Re(de)fining the dendritic cell lineage. Nat Immunol 13: 1145-1154, 2012.

29. Blum JS, Wearsch PA and Cresswell P: Pathways of antigen processing. Annu Rev Immunol 31: 443-473, 2013.

30. van den Broeke LT, Daschbach E, Thomas EK, et al: Dendritic cell-induced activation of adaptive and innate antitumor immunity. J Immunol 171: 5842-5852, 2003.

31. Wilczyński JR: Th1/Th2 cytokines balance - yin and yang of reproductive immunology. Eur J Obstet Gynecol Reprod Biol 122: 136-143, 2005 .

32. Lindau D, Gielen P, Kroesen M, et al: The immunosuppressive tumour network: myeloid-derived suppressor cells, regulatory $\mathrm{T}$ cells and natural killer T cells. Immunology 138: 105-115, 2013.

33. Onoé K, Yanagawa Y, Minami K, et al: Th1 or Th2 balance regulated by interaction between dendritic cells and NKT cells. Immunol Res 38: 319-332, 2007.

34. Jadidi-Niaragh F and Mirshafiey A: The deviated balance between regulatory T cell and Th17 in autoimmunity. Immunopharmacol Immunotoxicol 34: 727-739, 2012

35. Gill D and Tan PH: Induction of pathogenic cytotoxic T lymphocyte tolerance by dendritic cells: a novel therapeutic target. Expert Opin Ther Targets 14: 797-824, 2010.

36. Santegoets SJ, van den Eertwegh AJ, van de Loosdrecht AA, et al: Human dendritic cell line models for DC differentiation and clinical DC vaccination studies. J Leukoc Biol 84: 1364-1373, 2008. 